\title{
A MESSAGE OF FAREWELL.
}

WITu this, the February Number, the Editor's official con. nection with the Dublix Jorrn.ru of Medical Scinnce draws to a close. His tenure of office has been long--longer, indeed, than that of any of his predecessors-for it has lasted for fortyseven years. It was early in the year 1873 that Dr. James Little invited his co-operation in the editing of the Journal. Not long afterwards Dr. Little handed over the editorial duties wholly into his hands. Ninety-four volumes of the Journal have been prepared for publication by the present Editor, who now survenders into rounger and active hands the task which through all those years was to him one of lore rather than of toil.

The Editor cannot relinquish his office, which he ever regarded as one of great honour, as it was surely one of grave responsibility, without recording his grateful sense of the generous help at all times afforded him by his colleagues on the staff of the Journal.

$\mathrm{He}$ would also thankfully acknorvedge the loyalty and patriotism which his professional brethren ever placed at his service. With their valued aid, he has tried-not altogether unsuccessfully he is bold enough to think-to render a Medical Journal, which dates from the year 1832 and includes in its Roll of Editors the names of Graves, Stokes, Wilde, Kidd, and James Little-worthy of Ireland and of its capital.

To his successor the Editor offers his best wishes, and also to the Royal Academy of Medicine in Ireland, of which the Dublin Jocrnal of Menicil. Sciexce will be in future the official organ.

JoHN W. MoORe, M.D., Editor.

January 21, 1920. 